\title{
Positional Analysis of Guinea Pig Inner Hair Cell Membrane Conductances: Implications for Regulation of the Membrane Filter
}

\author{
Nicholas P. Raybould, Daniel J. Jagger, and Gary D. Housley \\ Molecular Physiology Laboratory, Physiology Division, Faculty of Medical and Health Sciences, \\ University of Auckland, Auckland, New Zealand
}

Received: 30 October 2000; Accepted: 12 April 2001; Online publication: 10 October 2001

\begin{abstract}
In mammals, sound transduction by inner hair cells (IHC) generates a receptor potential whose amplitude and phase drive auditory nerve firing. The membrane filter properties that define the input-output function of IHC are derived from membrane conductance and capacitance. These elements of the membrane filter were quantified using whole-cell voltage clamp of IHC from the four turns of the guinea pig cochlea. IHC membrane properties were remarkably constant along the cochlea, in contrast with all other auditory hair cell systems, and suggests that extrinsic processes such as the active filter provided by the outer hair cells are matched to a constant transfer function of the IHC. Two outwardly rectifying $\mathrm{K}^{+}$currents contribute to the IHC membrane conductance. These combined currents activate at approximately $-55 \mathrm{mV}$. IHC mean input resistance was $140 \mathrm{M} \Omega$ and capacitance was 10.0 $\mathrm{pF}$, generating a membrane time constant of $1.4 \mathrm{~ms}$ or a corner frequency of approximately $115 \mathrm{~Hz}$, which is consistent with reported low-frequency roll-off of the IHC AC receptor potential in vivo. Approximately $40 \%$ of the $313-1 \mathrm{nS}$ total $\mathrm{K}^{+}$conductance about $0 \mathrm{mV}$ was attributed to charybdotoxin-sensitive $\mathrm{K}_{\mathrm{Ca}}$ channels (also sensitive to cell dialysis with the $\mathrm{Ca}^{2+}$ chelator BAPTA or removal of extracellular $\mathrm{Ca}^{2+}$ ). The only known ligand-activated conductance in mature IHC,
\end{abstract}

Correspondence to: Gary D. Housley, Ph.D. • Molecular Physiology Laboratory • Physiology Division - Faculty of Medical and Health Sciences • University of Auckland • Private Bag 92019 • Auckland • New Zealand. Telephone: (64) (9) 3737 499; fax: (64) (9) 3737599 ext 6300; email: g.housley@auckland.ac.nz the P2X receptor conductance, averaged $31 \mathrm{nS}$ (activated by $400 \mu \mathrm{M}$ ATP; about $-75 \mathrm{mV}$ ) irrespective of cell origin. Thus, regulation of intracellular $\mathrm{Ca}^{2+}$ and activation of P2X receptors by extracellular ATP provide capacity for local dynamic fine-tuning of the IHC membrane filter.

Keywords: cochlea, P2X receptor, ATP, potassium channels, tonotopic, tuning

\section{INTRODUCTION}

Sound transduction in the mammalian cochlea can be separated into forward and reverse components (Mountain 1986; Dallos 1992; Ashmore and Kolston 1994). Forward transduction is the conversion of sound-induced fluid vibration in the cochlea to a phase-modulated receptor current passing through the mechanoelectric transducer (MET) channels, localized to the tips of the inner hair cell (IHC) and outer hair cell (OHC) stereocilia (Denk et al. 1995). This current produces a receptor potential across the hair cell basolateral membrane, determined by cell capacitance and conductance (the membrane filter), which initiates neurotransmitter release and drives auditory nerve firing. This process is conserved from lower-vertebrate sensory hair cell physiology (Art et al. 1986; Art and Fettiplace 1987; Hudsepth and Lewis 1988; Hudspeth 2000). Reverse transduction is specific to the mammalian cochlea and arises from the generation of a phase-related movement of the cell wall of the OHC (Ashmore 1987, 1994; Holley and Ashmore 1988; Kalinec et al. 1992; Santos-Sacchi 1992; Dallos and Evans 1995). This movement is derived from the 
receptor potential-generated conformation changes of the unique OHC electromotile protein Prestin (Zheng et al. 2000) and is the active substrate of the "cochlear amplifier" (Ashmore 1987, 1994; Kolston 1999). In conjunction with the passive mechanical filtering properties of the organ of Corti, the OHCs focus and enhance the sound energy to the IHCs in a frequencyspecific (tonotopic) manner (Kolston 1999). Transduction of this integrated stimulus by the IHC, the primary sensory cell mediating auditory neurotransmission (Ashmore 1994), generates the exquisite selectivity and sensitivity of the mammalian cochlea.

In lower vertebrates the absence of the cochlear amplifier tuning mechanism is mitigated by an electrical tuning of the hair cell membrane properties (Fettiplace and Fuchs 1999 for a review). This mechanism depends upon a tonotopic variation of $\mathrm{Ca}^{2+}$-activated $\mathrm{K}^{+}$channel $\left(\mathrm{K}_{\mathrm{Ca}}\right)$ properties that optimize the transduction of the stimulus for a given position along the basilar papilla (cochlea) (Wu et al. 1995; Navaratnam et al. 1997; Rosenblatt et al. 1997; Jones et al. 1999a,b) .

Given the abstraction of the tuning process away from the IHCs in the mammalian cochlea, the present study assessed the potential for the IHC membrane filter to provide tonotopic conditioning of the transduction current. The IHC membrane conductance, and hence the membrane filter, is largely determined by $\mathrm{Ca}^{2+}$-independent $\mathrm{K}^{+}$(Kros and Crawford 1990) and $\mathrm{K}_{\mathrm{Ca}}$ conductances (Housley et al. 1993; Dulon et al. 1995; Appenrodt and Kros 1997; Kros et al. 1998). In addition, IHC also exhibit an ATP-activated (P2X receptor) conductance localized to the apical (endolymphatic) surface which modulates the driving force for sound transduction (Housley et al. 1993, 1998a, 1999; Sugasawa et al. 1996; Housley 2000). The observed constancy of the IHC membrane filter properties suggests that IHCs perform a low-pass transfer of pretuned stimulus input (from the cochlear amplifier) that may be locally regulated by variations in intracellular $\mathrm{Ca}^{2+}$ or extracellular ATP.

\section{METHODS}

Guinea pig cochlear IHC were isolated and wholecell patch clamp recordings were made as described previously for OHCs (Raybould and Housley 1997). Experiments were performed with approval from the University of Auckland Animal Ethics Committee. Guinea pigs (160-1000 g, either sex, pigmented and albino) were euthanized by an overdose of anesthetic (sodium pentobarbitone $150 \mathrm{mg} \cdot \mathrm{kg}^{-1}$, Abbott Laboratories, North Chicago, IL, USA) injected into the intraperitoneal cavity. The temporal bones were removed and placed in an artificial (standard) perilymph solution (composition in $\mathrm{mM}$ : $\mathrm{NaCl} 140, \mathrm{KCl} 4, \mathrm{CaCl}_{2}$ 1.5,
$\mathrm{MgCl}_{2}$ 1.0, $\mathrm{NaH}_{2} \mathrm{PO}_{4}$ 2.0, $\mathrm{Na}_{2} \mathrm{HPO}_{4}$ 8.0, D-glucose 1, $\mathrm{pH} 7.25$ with $\mathrm{NaOH}$, osmolarity $=320 \mathrm{mOsm} \mathrm{L}^{-1}$ ). The otic capsule was split providing access to the cochlea, and a selected turn of organ of Corti was microdissected from the modiolus. The isolated turn was then incubated in $60 \mu \mathrm{L}$ of standard solution containing $0.25 \mathrm{mg} . \mathrm{mL}^{-1}$ trypsin (Sigma, St. Louis, MO, USA) for $10 \mathrm{~min}$. Following trituration to aid dissociation, the tissue was placed in an elongated $70 \mu \mathrm{L}$ microscope bath mounted on an inverted microscope (Nikon TMD, Tokyo, Japan) equipped with Nomarski differential interference contrast optics. Bath solutions were rapidly exchanged through superfusion $\left(500 \mu \mathrm{L} / \mathrm{min}^{-1}\right.$ ) by peristaltic pump (Gilson, Villiersle-Bel, France). All experiments were performed at room temperature $\left(20-22^{\circ} \mathrm{C}\right)$.

IHCs were selected for study if they possessed the following morphological properties: uniform flask shape, membrane birefringence, centrally located nucleus, intact stereocilia, and lack of Brownian motion in the cytoplasm (Fig. 1A). Images were captured continuously by video camera (Ikegami ICD 42E, CCD, Tokyo, Japan) and stored on sVHS videotape (Panasonic, Osaka, Japan). Cell dimensions (excluding stereocilia) were measured post hoc by image analysis software (Image Pro Plus, version 1.0, Media Cybernetics, Silver Spring, MD, USA) using an 8-bit videoframe grabber board (ITEX, Woburn, MA, USA). All measurements were made with $0.3 \mu \mathrm{m}$ resolution and corrected for the aspect ratio.

Recording electrodes (2-5 M $\Omega$; filamented borosilicate glass, Harvard Apparatus GC120 TF-10, Edenbridge, Kent, UK) were filled with an internal solution (in mM: KCl 140; $\mathrm{MgCl}_{2}$ 2.0, $\mathrm{NaH}_{2} \mathrm{PO}_{4}$ 1.0, $\mathrm{Na}_{2} \mathrm{HPO}_{4}$ 8.0, $\mathrm{CaCl}_{2}$ 0.01, either 1,2-bis(o-aminophenoxy)ethane- $N, N, N^{\prime}, N^{\prime}$-tetraacetic acid (BAPTA) 10 or ethylene glycol-bis $\left(\beta\right.$-aminoethyl ether)- $N, N, N^{\prime}, N^{\prime}$-tetraacetic acid (EGTA) 0.5, D-glucose 3.0, pH 7.25 with $\mathrm{KOH}$, osmolarity $=310-320 \mathrm{mOsm} \mathrm{L}^{-1}$ ). Whole-cell voltage clamp recordings were made using a patch clamp amplifier (Axopatch 200, Axon Instruments, Union City, CA, USA) controlled by computer software (pClamp 5.0, Axon Instruments) via an interface (Tecmar TL 1, Labmaster Scientific Solutions, Solon, Mentor, OH, USA). IHCs with stable current baselines and zero-current potentials $\left(V_{\mathrm{z}}\right)$ more negative than $-40 \mathrm{mV}$ were selected for study. Application of a 10 $\mathrm{mV}$ hyperpolarizing step $(50 \mathrm{~ms})$ from a holding potential of $-60 \mathrm{mV}$ permitted post hoc calculation of membrane resistance, capacitance $\left(C_{\mathrm{m}}\right)$, and series resistance $\left(R_{\mathrm{s}}\right)$ from the charging transient (sampled at $30 \mathrm{kHz}$ ). The mean series resistance derived after capacitance compensation was $5.0 \pm 0.2 \mathrm{M} \Omega(n=$ 226). Recordings were corrected online for bath potentials and $>95 \%$ series resistance-induced voltage 

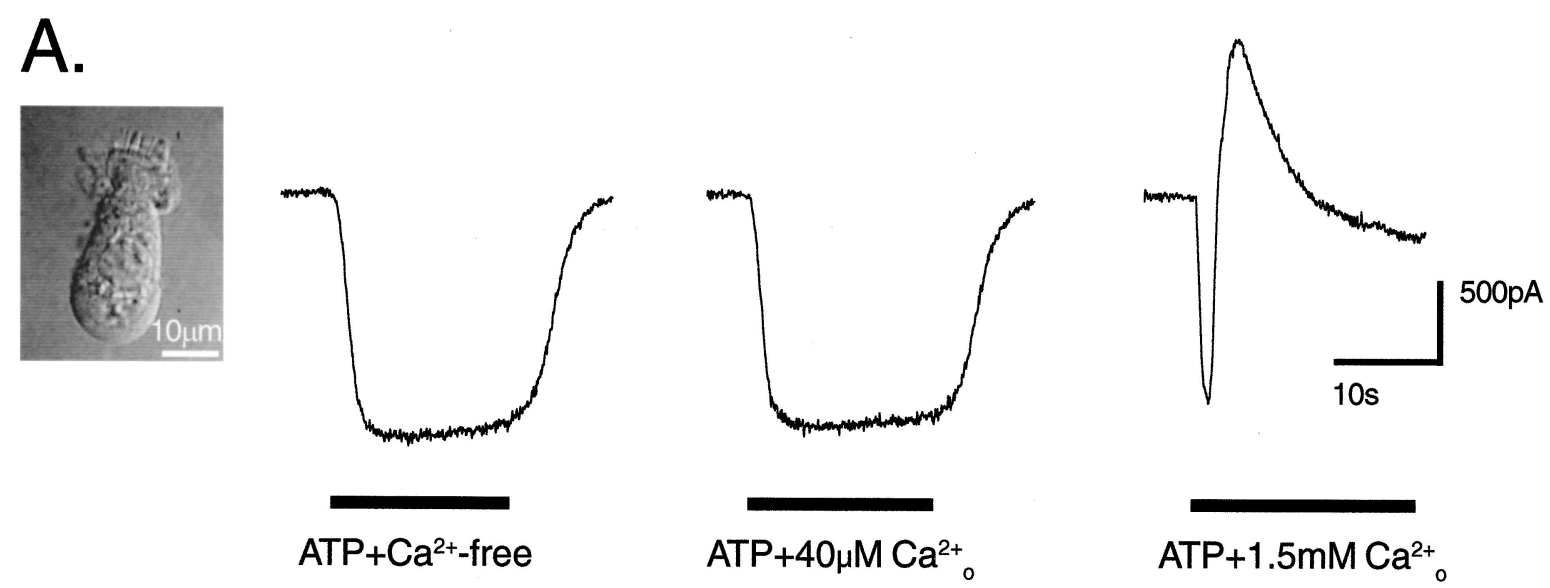

B.

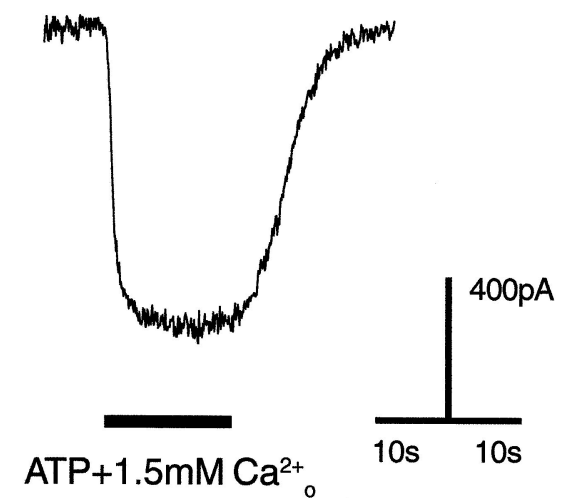

FIG. 1. Ancillary activation of $\mathrm{K}_{\mathrm{Ca}}$ conductance is mediated by $\mathrm{Ca}^{2+}$ entry through the inner hair cell ATP-gated ion channels. A. In $\mathrm{Ca}^{2+}$ free external solution or solution with endolymphatic $\mathrm{Ca}^{2+}$ levels (40 $\mu \mathrm{M})$, bath-applied ATP $(100 \mu \mathrm{M})$ produced a sustained inward current $\left(V_{\mathrm{h}}=-60 \mathrm{mV}\right)$ that was reversible with washout (internal solution includes $0.5 \mathrm{mM}$ EGTA). Subsequent application of ATP with 1.5 $\mathrm{mM} \mathrm{Ca}^{2+}$ in standard external solution resulted in a biphasic current response, where the inward current was transient and later masked by the developing outward current (right trace). Note that this outward current declined prior to the end of the ATP application, an effect

error. Junction potential was not corrected for (estimated at $-3 \mathrm{mV}$ for the external/internal solutions used). Data from voltage-step protocols was filtered online using the patch clamp amplifier, 4-pole lowpass Bessel filter $(10 \mathrm{kHz})$ and digitized at $20 \mathrm{kHz}$. The recording time constant was approximately $50 \mu \mathrm{s}$ based on the average of the $R_{\mathrm{s}} \times C_{\mathrm{m}}$ data and the limiting factor of the temporal resolution of the voltage clamp.

In experiments studying $K_{\mathrm{Ca}}$ channel block, ATP (disodium salt, Sigma) was pressure applied via a double-barreled glass pipette controlled by a computergated solenoid (Mac Valve Pacific Ltd., Auckland, New Zealand) and co-applied with either of the blockers iberiotoxin and charybdotoxin (Alomone Labs, Jerusalem, Israel).
IHC slope conductances were derived from currentvoltage relationships $(I / V)$ obtained directly from voltage ramps $(-100$ to $+50 \mathrm{mV} ; 1 \mathrm{~s})$. These voltage ramps were repeated every $5 \mathrm{~s}$ in experiments to monitor changes in membrane conductance. Initial superfusion of standard solution was followed by superfusion of nominally $\mathrm{Ca}^{2+}$-free solution (where $1.5 \mathrm{mM} \mathrm{CaCl}_{2}$ was replaced with $\mathrm{MgCl}_{2}$; estimated at $3 \mu \mathrm{M} \mathrm{Ca}^{2+}$ based on published residual levels in buffer stocks). The $\mathrm{Ca}^{2+}$ free external solution along with BAPTA in the internal solution minimized background $\mathrm{K}_{\mathrm{Ca}}$ channel activation. ATP was applied by bath substitution at two concentrations: (1) $10 \mu \mathrm{M}$, close to the $E C_{50}$ of the ATP-gated currents in IHCs and (2) a supramaximal dose of $400 \mu \mathrm{M}$ (Sugasawa et al. 1996). The $I / V$ of the P2X receptor conductance was calculated by sub- 
traction of the control $I / V$ in $\mathrm{Ca}^{2+}$-free solution from the $I / V$ obtained during the superfusion of ATP in $\mathrm{Ca}^{2+}$-free medium. Membrane conductance was determined from the $I / V$ about $-75 \mathrm{mV}\left(G_{-75 \mathrm{mV}}\right)$ and about $0 \mathrm{mV}\left(G_{0 \mathrm{mV}}\right)$ as the slope between -60 and $-90 \mathrm{mV}$ and -10 and $+10 \mathrm{mV}$, respectively.

The kinetics of channel opening was determined from the current responses elicited by a series of voltage steps $(-100$ to $+30 \mathrm{mV}, 10 \mathrm{mV}$ increments, 40 $\left.\mathrm{ms}, V_{h}=-60 \mathrm{mV}\right)$. The activation time constant of the outward current was best fitted by a single exponential $I(t)=A \exp [-(t-K) / \tau]+c$, where $A$ is the current amplitude, $K$ is the time at the start of the fit, $\tau$ is the time constant, $c$ is the offset over the first $2 \mathrm{~ms}$ for fast channel kinetics or from 3 to $40 \mathrm{~ms}$ for slower channel kinetics (Clampfit 6.0, Axon Instruments).

Differences were considered statistically significant at the $p<0.05$ level. We used the statistical package SyStat (SYSTAT Inc., Evanston, IL, USA) to perform one-way analysis of variance (ANOVA) and paired and unpaired Student's $t$-tests where appropriate. Data are presented as mean \pm SEM.

\section{RESULTS}

The average IHC length was $28.6 \pm 0.2 \mu \mathrm{m}$ and the average cell width was $15.8 \pm 0.2 \mu \mathrm{m}$, with no significant variation between cells from the four turns of the cochlea ( $p>0.05$; one-way ANOVA; $n=297)$. Under whole-cell voltage clamp, IHCs exhibited marked outward rectification of voltage-activated currents comparable to previous reports of IHCs with low resting intracellular $\mathrm{Ca}^{2+}$ levels (Dulon et al. 1995; Sugasawa et al. 1996). IHC capacitance $\left(C_{\mathrm{m}}\right)$ had an average of $10.0 \pm 0.2 \mathrm{pF}(n=226$; measured between -60 and $-70 \mathrm{mV})$ and was independent of cell origin $(p>$ $0.05 ; n=125)$. The average initial zero-current potential $\left(V_{\mathrm{z}}\right)$ of the IHCs, determined upon breakthrough to whole-cell recording, was independent of intracellular $\mathrm{Ca}^{2+}$ buffering $\left(p>0.05 ; V_{\mathrm{z}}=-56.8 \pm 1.0 \mathrm{mV}, n\right.$ $=69,10 \mathrm{mM}$ BAPTA; $V_{\mathrm{z}}=-57.4 \pm 0.8 \mathrm{mV}, n=84$, $0.5 \mathrm{mM}$ EGTA).

Interaction of $\mathrm{K}_{\mathrm{Ca}}$ and $\mathrm{P} 2 \mathrm{X}$ receptor conductances

The aim of this study was to quantify the principal voltage- and ligand-activated conductances of IHCs in order to measure their contribution to the membrane filter with respect to cell origin along the organ of Corti. The potential for interaction between $\mathrm{K}_{\mathrm{Ca}}$ conductance, activated by both voltage and $\mathrm{Ca}^{2+}$ (Toro et al. 1998), and ATP-activated (P2X receptor) conductance that exhibits a significant $\mathrm{Ca}^{2+}$ permeability
(Evans et al. 1996) necessitated the establishment of protocols for isolation of the individual conductances. The experiments described below indicate that secondary activation of $\mathrm{K}_{\mathrm{Ca}}$ conductance during ATP application could be blocked using nominally $\mathrm{Ca}^{2+}$ free conditions, significant intracellular $\mathrm{Ca}^{2+}$ chelation, or selective $\mathrm{K}_{\mathrm{Ca}}$ channel blockers. In addition, these experiments established that under physiological (endolymphatic) $\mathrm{Ca}^{2+}$ levels, ATP is unlikely to cause activation of $\mathrm{K}_{\mathrm{Ca}}$ channels via $\mathrm{Ca}^{2+}$ entry through the $\mathrm{P} 2 \mathrm{X}$ receptors. However, ATP will depolarize the IHCs and therefore recruit voltage-activated conductances.

In initial experiments with IHCs isolated from throughout the organ of Corti, using standard solution (containing $1.5 \mathrm{mM} \mathrm{Ca}^{2+}$ ), and with low intracellular $\mathrm{Ca}^{2+}$ buffering (0.5 mM EGTA), bath application of extracellular ATP $(100 \mu \mathrm{M})$ produced a biphasic current profile where the initial inward current was followed by activation of an outward current (Fig. 1A, right trace). This substantial outward current has been attributed to secondary activation of $\mathrm{K}_{\mathrm{Ca}}$ channels via $\mathrm{Ca}^{2+}$ influx through the ATP-gated ion channels (Housley et al. 1993; Dulon et al. 1995; Sugasawa et al. 1996). The mean delay between the onset of the inward current and subsequent inflection resulting from the activation of the $\mathrm{K}_{\mathrm{Ca}}$ conductance was 866 $\pm 99 \mathrm{~ms}(n=16)$. In nominally $\mathrm{Ca}^{2+}$-free solution, bath application of ATP typically produced a sustained inward current response (Fig. 1A, left trace). Similar results were obtained using an endolymphatic level of $\mathrm{Ca}_{0}^{2+}$ [40 $\mu \mathrm{M}$ (Gill and Salt 1997); Fig. 1A, center trace], while subsequent exposure to ATP in $1.5 \mathrm{mM} \mathrm{Ca}_{0}^{2+}$ resulted in a biphasic current response. With an increased level of intracellular $\mathrm{Ca}^{2+}$ buffering $(10 \mathrm{mM}$ BAPTA), bath-applied ATP produced a sustained inward current with $1.5 \mathrm{mM} \mathrm{Ca}_{0}^{2+}$ ( $n=10$; Fig. 1B). In standard solution (with $0.5 \mathrm{mM}$ EGTA in the recording pipette solution), pipette co-application of ATP $(100 \mu \mathrm{M})$ with iberiotoxin $(1 \mu \mathrm{M})$, a potent blocker of slo-type $\mathrm{K}_{\mathrm{Ca}}$ channels (Kaczorowski et al. 1996; Toro et al. 1998), either failed to activate the outward $\mathrm{K}_{\mathrm{Ca}}$ conductance (sustained inward current response, $n=5$; data not shown) or produced a greatly attenuated biphasic response $(n=6$; Fig. 1C).

The role of the $\mathrm{K}_{\mathrm{Ca}}$ conductance in the generation of the biphasic current response to ATP was further examined using charybdotoxin (ChTx; Kazorowski et al. 1996). In standard solution, application of ATP $(100 \mu \mathrm{M})$ with ChTx $(1 \mu \mathrm{M})$ from a single micropipette barrel produced a sustained or weakly desensitizing inward current of $-1289 \pm 128 \mathrm{pA}(n=31$; Fig. 2A). After washout of the ChTx, $100 \mu \mathrm{M}$ ATP in standard solution (from the second barrel of the drug pipette) produced a rapid biphasic current response 
A.

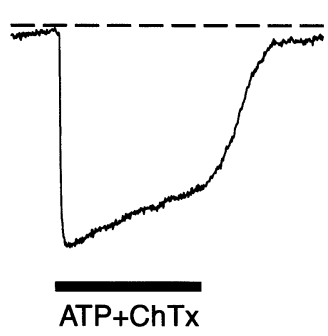

B.

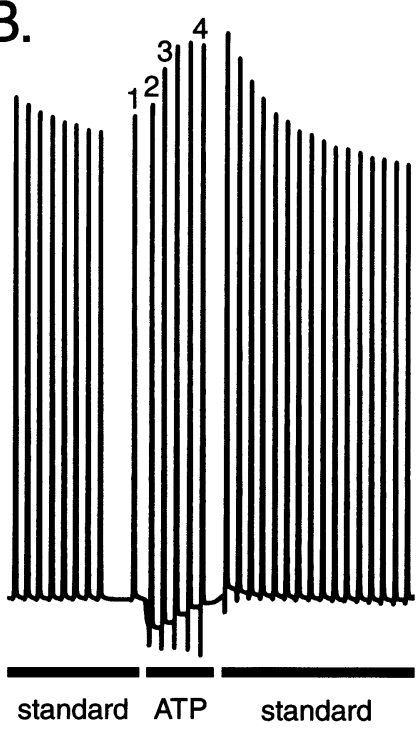

C.

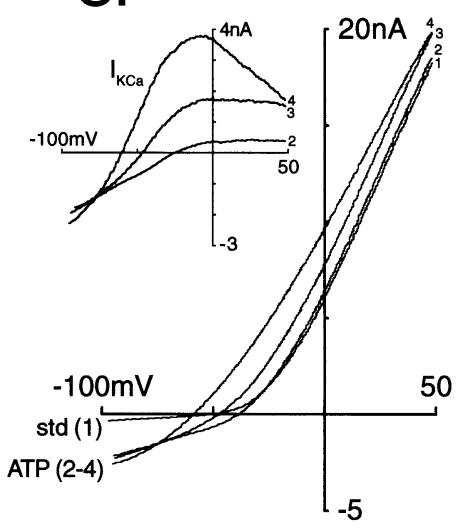

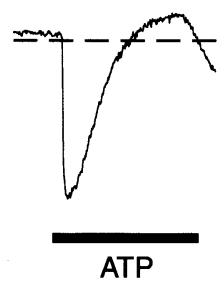

ATP
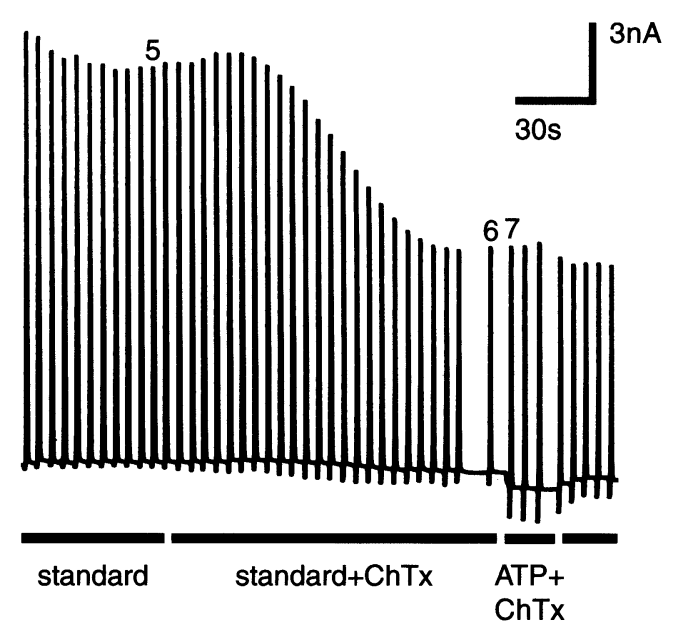

D.

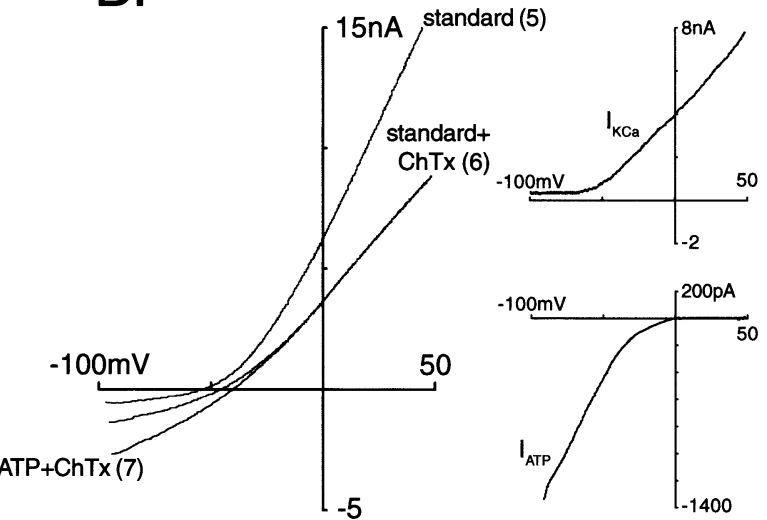

FIG. 2. The biphasic current response to extracellular ATP is mediated by charybdotoxin (ChTx)sensitive $\mathrm{K}_{\mathrm{Ca}}$ channels. A. In standard solution, co-application of 100 $\mu \mathrm{M}$ ATP and $1 \mu \mathrm{M}$ ChTx by micropipette produced a slowly desensitizing inward current response. Subsequent application of $100 \mu \mathrm{M}$ ATP alone produced a rapid biphasic current response $\left(V_{\mathrm{h}}=-60\right.$ $\mathrm{mV}$ ). Note that the outward current phase declined prior to the end of the ATP application, an effect we attribute to recruitment of uncharacterized inward current. Dashed line indicates zero current. B. Chart record of IHC current during repeated voltage ramps $(-100$ to $\left.+50 \mathrm{mV}, 1 \mathrm{~s}, 0.2 \mathrm{~Hz}, V_{\mathrm{h}}=-60 \mathrm{mV}\right)$ during bath application of ATP (100 $\mu \mathrm{M})$, with and without ChTx (1 $\mu \mathrm{M})$. Note that the ATP-mediated activation of the $\mathrm{K}_{\mathrm{Ca}}$ conductance, evident as an increase in peak outward current (traces 2-4), is blocked by ChTx (trace 7). C. Recruitment of $\mathrm{K}_{\mathrm{Ca}}$ conductance during the ATP response in standard solution is detailed by the currentvoltage relationships $(I / V)$ plotted from traces 1-4 from $\mathbf{B}$. ATP initially produced a depolarizing shift in $V_{z}$ (standard: trace $1=-51 \mathrm{mV}$, ATP; trace $2=-39 \mathrm{mV}$ ) with subsequent hyperpolarizing shifts arising from recruitment of the $\mathrm{K}_{\mathrm{Ca}}$ conductance (trace $3=-48 \mathrm{mV}$, trace $4=-60$ $\mathrm{mV}$; detail shown in the inset). Traces in the inset were obtained by subtracting control trace (1) from traces 2-4. D. Detail of the $I / V$ records obtained during ChTx block (100 nM in the bath) of the $\mathrm{K}_{\mathrm{Ca}}$ conductance shown in $\mathbf{B}$ (trace 5, control $V_{\mathrm{z}}=-55 \mathrm{mV}$; ChTx block, trace $6, V_{z}=-46 \mathrm{mV}$ ) and subsequent ATP-gated inward current during ChTx block (pipette application: $100 \mu \mathrm{M}$ ATP, $1 \mu \mathrm{M}$ ChTx). In the presence of ChTx, ATP caused a sustained depolarizing shift in $V_{z}$ to $-41 \mathrm{mV}$ (trace 7 ). Upper inset: The ChTx-sensitive $\mathrm{K}_{\mathrm{Ca}}$ current $\left(I_{\mathrm{KCa}}\right.$ derived by subtracting trace 6 (ChTx block) from trace 5 (standard). Lower inset: ATP-gated current $\left(I_{\text {ATP }}\right)$ derived by subtracting trace 6 (ChTx block) from trace 7 (ATP + ChTx). Note that the reversal potential of the ATP-gated current (with ChTx) is close to $0 \mathrm{mV}$. 
in $11 / 25$ cells (Fig. 2A) (peak inward current $=-1108$ $\pm 96 \mathrm{pA}, n=25)$.

The secondary activation of the $\mathrm{K}_{\mathrm{Ca}}$ conductance during the biphasic ATP response was evident from a progressive leftward shift toward the calculated $E_{\mathrm{K}}$ $(-90 \mathrm{mV})$ in the current-voltage $(I / V)$ relationship of the IHCs (measured using repeated voltage ramps, -150 to $+100 \mathrm{mV}, 1 \mathrm{~s}, 0.2 \mathrm{~Hz}$ ) in standard solution (Figs. 2B and C). The derived $I / V$ of the ATP-activated conductance (bath application) illustrates the progressive recruitment of the $\mathrm{K}_{\mathrm{Ca}}$ conductance following an initial inwardly rectifying $\mathrm{P} 2 \mathrm{X}$ receptor conductance (Fig. 2C, inset). This rectification resulted in an ATPinduced increase of the average IHC slope conductance about $-75 \mathrm{mV}$ from $17.3 \pm 3.1$ to $83.5 \pm 10.0$ $\mathrm{nS}(n=24)$. The slope of the $I / V$ s measured about $0 \mathrm{mV}$ (standard $=202.1 \mathrm{nS}$, ATP $=210.5 \mathrm{nS}$ ) did not vary significantly ( $p>0.05$, paired $t$-test; see Fig. 2C). In six of these experiments, we subsequently superfused ChTx (100 nM) to assess the $\mathrm{K}_{\mathrm{Ca}}$ conductance. Two experiments were subsequently excluded because the baseline conductance did not fully recover from the preceding ATP challenge. In the remaining four cells, ChTx produced a $45 \%$ reduction in mean slope conductance about $0 \mathrm{mV}$ from $169.1 \pm 11.7$ to $93.3 \pm$ $11.9 \mathrm{nS}$, with no significant effect on the conductance about $-75 \mathrm{mV}$ (standard $=18.3 \pm 4.6 \mathrm{nS}$ to standard $+\operatorname{ChTx}=14.8 \pm 4.5 \mathrm{nS}$; Figs. 2B and D). These changes in membrane conductance with the addition of ChTx to the external solution were associated with a depolarizing shift in $V_{\mathrm{z}}$ from a mean of $-58.3 \pm 1.2$ to $-50.8 \pm 2.0 \mathrm{mV}$. The $\mathrm{ChT}$-sensitive $\left(\mathrm{K}_{\mathrm{Ca}}\right)$ conductance was isolated by subtracting the $I / V$ trace obtained during ChTx perfusion from the control I/ $V$ (Figs. 2B and D). The activation threshold of this conductance, determined from the derived $I / V$ (Fig. 2D, upper inset) as the intersection of the tangents of the upward slope of the current trace with the slope of the trace negative to $-60 \mathrm{mV}$, had a mean of -52.3 $\pm 1.9 \mathrm{mV}(n=4)$. In comparison, addition of $100 \mathrm{nM}$ iberiotoxin to standard solution produced a smaller $(25 \%)$ reduction in membrane conductance about 0 $\mathrm{mV}$ from a mean of $120.7 \pm 30.0$ to $89.7 \pm 13.2 \mathrm{nS}$ $(n=4)$.

Bath application of $100 \mu \mathrm{M}$ ATP produced a sustained inward-current response in the presence of 1 $\mu \mathrm{M}$ ChTx $(n=23)$, with an increase in slope conductance about $-75 \mathrm{mV}$ of $35.8 \pm 2.3 \mathrm{nS}(n=4)$. The $I / V$ of the net ATP-gated current showed pronounced inward rectification, reversing close to $0 \mathrm{mV}$ (Fig. 2D, lower inset).

These experiments established the considerable dynamic range of IHC conductance regulated by intracellular $\mathrm{Ca}^{2+}$ and extracellular ATP. Subsequent experiments utilized these protocols for isolating $\mathrm{K}_{\mathrm{Ca}}$ and
ATP-gated channel activation to quantify IHC membrane conductance properties with respect to cell origin in each of the four turns of the guinea pig cochlea.

Voltage-activated potassium conductances with respect to cell origin

In the guinea pig cochlea, the basal (first) turn encodes frequencies approaching $45 \mathrm{kHz}$, whereas the apical (turn 4) region encodes low-frequency sound $(<250 \mathrm{~Hz}$, Pujol et al. 1992). Voltage ramps ( -150 to $+100 \mathrm{mV}, 1 \mathrm{~s}$ ) applied within $5 \mathrm{~s}$ of breakthrough to whole-cell configuration (prior to $10 \mathrm{mM}$ BAPTA dialysis) revealed an outwardly rectifying conductance with a mean threshold of activation of $-56 \pm 2.1$ $\mathrm{mV}$ ( $n=69$; Fig. 3). This represented the combined activation of the $\mathrm{K}_{\mathrm{Ca}}$ conductance, described above, and $\mathrm{Ca}^{2+}$-insensitive outwardly rectifying $\mathrm{K}^{+}$conductance (Kros and Crawford 1990).

There was no evidence for a systematic variation in IHC voltage-activated potassium conductances with respect to cell origin. Membrane conductances about -75 or $0 \mathrm{mV}$ measured immediately after establishing whole-cell recording showed no difference with respect to turn of origin ( $p>0.05$, one-way ANOVA; Figs. $4 \mathrm{~A}$ and $\mathrm{B})$. Conductance measured about -75 $\mathrm{mV}\left(\mathrm{G}_{-75 \mathrm{mV}}\right)$ ranged from 1.6 to $24.4 \mathrm{nS}$ with a mean of $7.3 \pm 1.2 \mathrm{nS}(n=69$; Figs. $4 \mathrm{~A}$ and $\mathrm{C})$, equivalent to an input resistance of approximately $140 \mathrm{M} \Omega$. Membrane conductance about $0 \mathrm{mV}\left(\mathrm{G}_{0 \mathrm{mV}}\right)$ ranged from 52.5 to $634 \mathrm{nS}$ with a mean of $313 \pm 16.3 \mathrm{nS}(n=69$; Figs. $4 \mathrm{~B}$ and $\mathrm{D}$ ), equivalent to an input resistance of only $3 \mathrm{M} \Omega$. The modes of the histograms for IHC conductance about $0 \mathrm{mV}$ were between 200 and 400 $\mathrm{nS}$ for all four turns (Fig. 4B). Intraturn variability here may mask interturn differences, but the histogram profiles make this unlikely.

Repeated voltage ramps $(-100$ to $+50 \mathrm{mV}, 1 \mathrm{~s}, 0.2$ $\mathrm{Hz}$ ) showed a stabilizing reduction in $\mathrm{K}_{\mathrm{Ca}}$ conductance over approximately $7 \mathrm{~min}$ after breakthrough to wholecell configuration (Fig. 3A), consistent with previously reported buffering of intracellular $\mathrm{Ca}^{2+}$ by BAPTA in IHC following the onset of voltage clamp (Sugasawa et al. 1996). The reduction in membrane conductance was not observed when the lower-affinity $\mathrm{Ca}^{2+}$ chelator EGTA $(0.5 \mathrm{mM})$ was included in the recording pipette. This is consistent with the differential effect of these two $\mathrm{Ca}^{2+}$ buffers on the ATP-induced secondary activation of $\mathrm{K}_{\mathrm{Ca}}$ channels (compare Figs. 1A and B). With BAPTA dialysis, the mean steady-state membrane conductance about $0 \mathrm{mV}$ was $188.0 \pm 13.0 \mathrm{nS}(n=62$; Fig. 4D), indicating, as found with the ChTx experiments, that the $\mathrm{K}_{\mathrm{Ca}}$ conductance accounts for approximately $40 \%$ of the outwardly rectifying conductance. The conductance measured about $-75 \mathrm{mV}$ slightly increased under these conditions (steady-state mean 


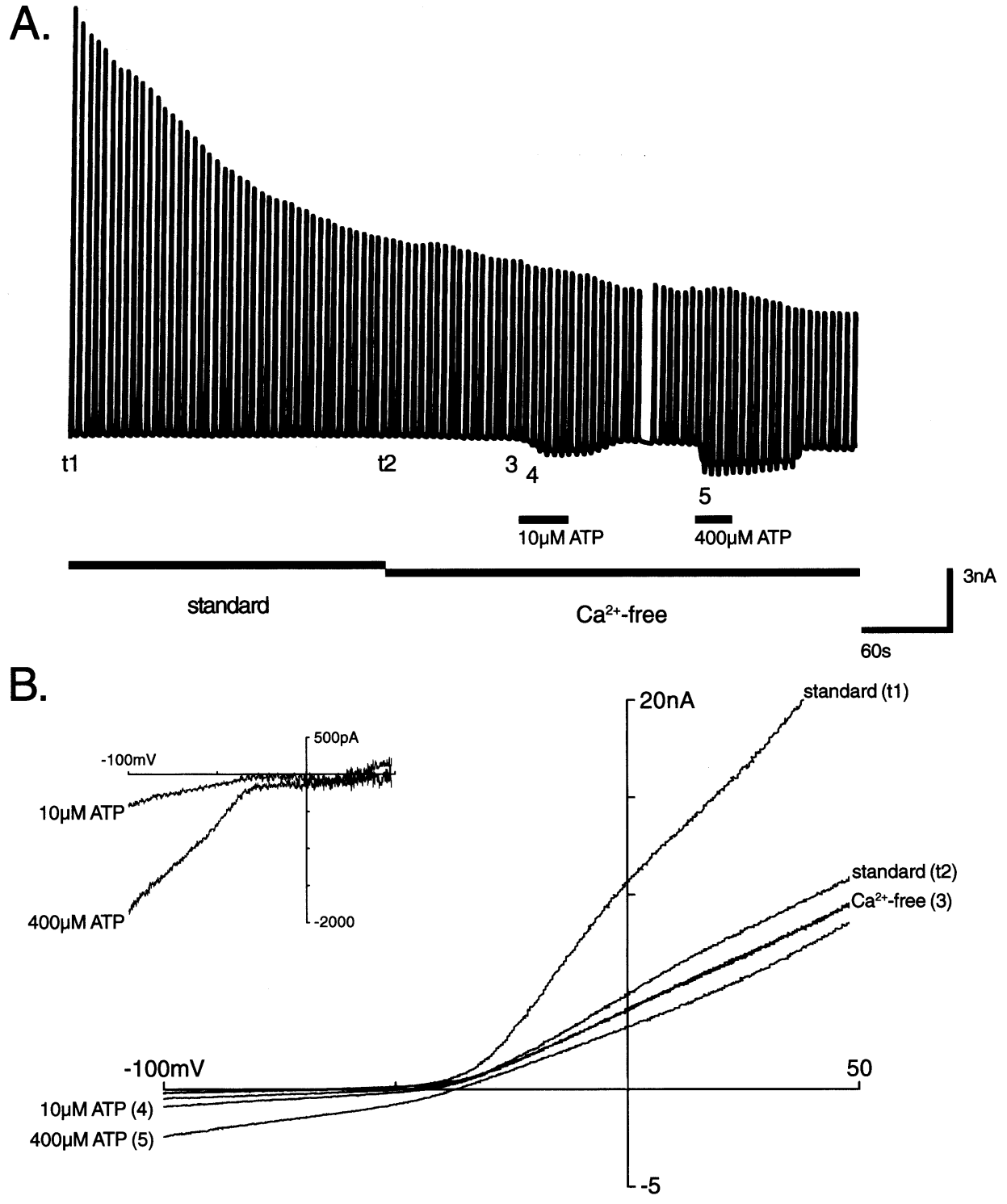

FIG. 3. Voltage-activated and ATP-activated conductances of an isolated IHC. A. Chart record showing the current trace during the sequential superfusion of standard solution, $\mathrm{Ca}^{2+}$-free solution, $10 \mu \mathrm{M}$ ATP in $\mathrm{Ca}^{2+}$-free solution, $\mathrm{Ca}^{2+}$-free wash, $400 \mu \mathrm{M}$ ATP in $\mathrm{Ca}^{2+}$-free solution, and $\mathrm{Ca}^{2+}$-free washout (voltage ramp protocol: -100 to $+50 \mathrm{mV}, 1 \mathrm{~s}, 0.2 \mathrm{~Hz}, V_{\mathrm{h}}=-60$ $\mathrm{mV})$. A progressive reduction in the outward component of the currentvoltage $(I / V)$ relationship is evident during the initial recording phase in standard solution because of dialysis of the IHCs by $10 \mathrm{mM}$ BAPTA (comparison of $\mathrm{t} 2$ with $\mathrm{t} 1$, where $\mathrm{t} 1$ was obtained approximately 200 s after establishing whole-cell recording). Subsequent superfusion of $\mathrm{Ca}^{2+}$-free solution produced a further small reduction in the outward component of the I/ $V$ (trace 3). Application of $10 \mu \mathrm{M}$ ATP in $\mathrm{Ca}^{2+}$-free solution produced an inward current of $-608 \mathrm{pA}\left(V_{\mathrm{h}}\right.$ $=-60 \mathrm{mV}$ ), seen as a downward shift in the current trace (trace 4) that was reversible with washout. Subsequent application of a supramaximal concentration of ATP (400 $\mu \mathrm{M})$ produced an inward current of $-998 \mathrm{pA}$ (trace 5). B. $I / V$ relationships of the voltage-activated and ATP-activated conductances (traces labeled in A). Inset shows the inward rectification of the net $\mathrm{P} 2 \mathrm{X}$ receptor conductance, determined by subtraction of the $I / V$ in $\mathrm{Ca}^{2+}$ free solution from the $I / V$ with ATP in $\mathrm{Ca}^{2+}$-free solution.
$=14.0 \pm 0.9 \mathrm{nS}, p<0.05$, unpaired $t$-test, $n=62$; Fig. 4C). The lack of turn-dependent variation in steady-state membrane conductance about both -75 and $0 \mathrm{mV}$ is shown in Figure 7 .

Subsequent superfusion of these IHCs with nominally $\mathrm{Ca}^{2+}$-free solution produced a mean depolarizing shift in $V_{z}$ of $6.4 \mathrm{mV}$ (mean $V_{z}=-50.4 \pm 1.0 \mathrm{mV}$, $n=56, p<0.05)$. These changes in $V_{\mathrm{z}}$ in $\mathrm{Ca}^{2+}$-free solution were independent of IHC origin $(p>0.05$, one-way ANOVA). There was a significant $(p<0.05)$ depolarizing shift in the threshold voltage of the outwardly rectifying conductance, to an average onset in $\mathrm{Ca}^{2+}$-free solution of $-46.8 \pm 2.8 \mathrm{mV}(n=56)$. Together, these data are consistent with the further suppression of a residual $\mathrm{K}_{\mathrm{Ca}}$ conductance.

Removal of $\mathrm{Ca}_{0}^{2+}$ decreased the membrane conductance about $0 \mathrm{mV}$ to $160.2 \pm 11.7 \mathrm{nS}$, a significant decline compared with levels at steady state in standard solution ( $p<0.05$, paired $t$-test, $n=56$; Fig. 4D). The relatively small background conductance at $-75 \mathrm{mV}$ showed variable changes with the switch to the $\mathrm{Ca}^{2+}$ free solution (average $=16.25 \pm 1.2 \mathrm{nS}, n=56$; Fig. $4 \mathrm{C})$. The residual $\mathrm{Ca}^{2+}$-insensitive voltage-activated conductance determined at both -75 and $0 \mathrm{mV}$ was independent of cell origin ( $p>0.05$, one-way ANOVA; Fig. 7).

The preceding experiments showed that there was no variation in magnitude of the voltage-activated conductances with respect to cell origin. However, we also considered the possibility that a variation in the kinetic properties of the voltage-activated channels could provide a basis for IHC tuning [as noted for $\mathrm{K}_{\mathrm{Ca}}$ channels in lower-vertebrate hair cells (Fettiplace and Fuchs, 1999) ]. To address this issue, we undertook a separate series of experiments to characterize the activation kinetics of IHC membrane currents in response to 
A
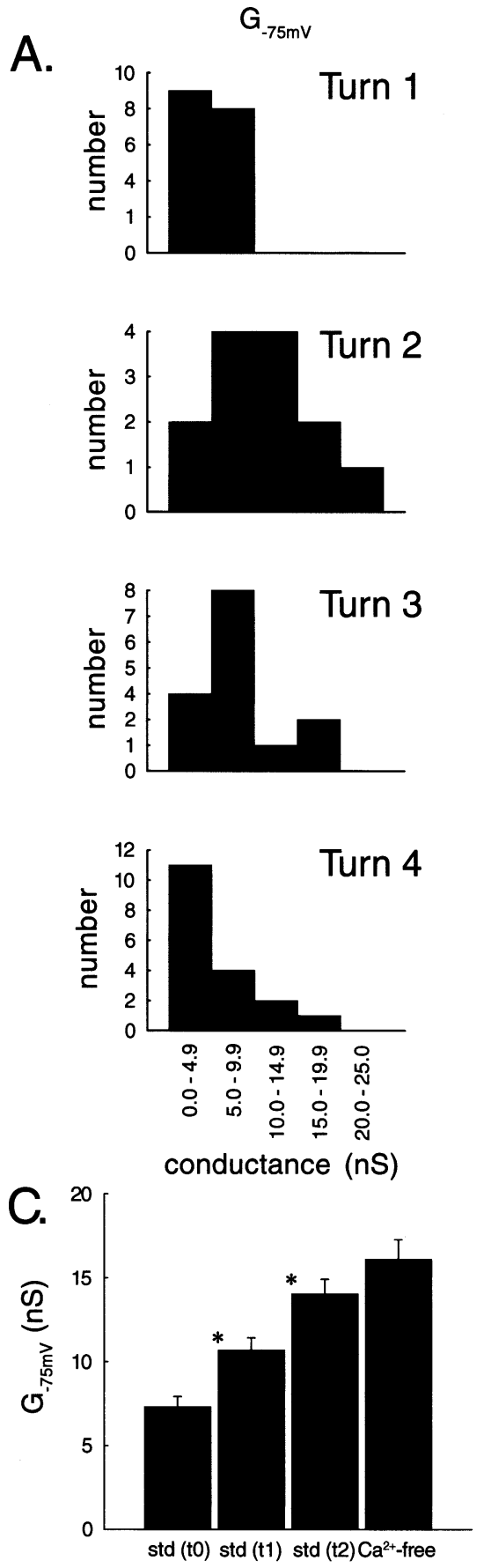

B.
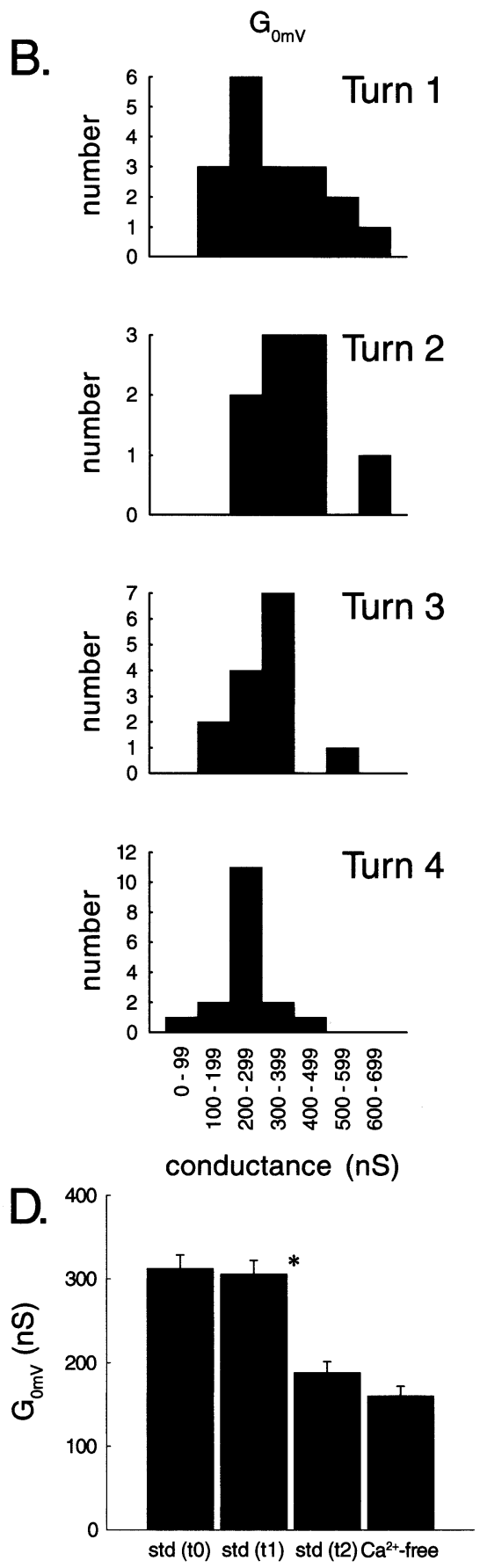

FIG. 4. Summary of the voltage-activated conductances of IHCs isolated from all four turns of the cochlea. A, B. Comparison of the distribution of slope conductance measured about $-75 \mathrm{mV}\left(G_{-75 \mathrm{mV}}\right)$ and $0 \mathrm{mV}\left(G_{0 \mathrm{mV}}\right)$ within $5 \mathrm{~s}$ of attaining whole-cell recording shows no systematic variation across the cochlear turns. C. Slope conductance about $-75 \mathrm{mV}\left(G_{-75 \mathrm{mV}}\right)$ increased during dialysis of the cell with BAPTA and exposure to $\mathrm{Ca}^{2+}$-free solution [std (t0) = initial conductance; std $(\mathrm{t} 1)=$ conductance 60-180 s after std (t0); std $(\mathrm{t} 2)=$ steady state immediately prior to $\mathrm{Ca}^{2+}$. free solution $]^{*}$ indicates significant difference ( $p<0.05$, unpaired $t$-test for adjacent bars. D. Slope conductance about $0 \mathrm{mV}\left(G_{0 \mathrm{mV}}\right)$ decreased during BAPTA dialysis and superfusion of $\mathrm{Ca}^{2+}$-free solution. Each bin in $\mathbf{C}$ and D represents the mean \pm SEM for a total of 56-69 IHCs. depolarizing voltage steps. These experiments used the lower cytosolic $\mathrm{Ca}^{2+}$ buffering (0.5 mM EGTA) to preserve the $\mathrm{K}_{\mathrm{Ca}}$ conductance. IHC from turns 1-3 $(n=38)$ and $14 / 23$ cells from turn 4 exhibited fast activation kinetics (Figs. 5A, B, and D) best fitted by a single exponential function over the first $2 \mathrm{~ms}$ (activation threshold approximately $-55 \mathrm{mV}$ ). Five turn 4 IHCs exhibited a variable mixture of fast- and slowactivating outward currents (obvious as a pronounced deviation from the single exponential fit to the initial $2 \mathrm{~ms}$ ); four IHCs had no fast component (Figs. 5C and $\mathrm{D}$, inset). The latter IHCs had activation thresholds of approximately $-30 \mathrm{mV}$, with a voltage-dependent activation best fitted (over $40 \mathrm{~ms}$ ) by slower single exponential functions with time constants that ranged from $51.8 \pm 5.4 \mathrm{~ms}$ at $-20 \mathrm{mV}$ to $10.6 \pm 0.7 \mathrm{~ms}$ at $+30 \mathrm{mV}$ (Fig. 5D, inset). During the initial $2 \mathrm{~ms}$, the activation kinetics of IHCs from turns 1 and 2 were faster than those of IHCs from turns 3 and $4(p<$ 0.05 , unpaired $t$-test; Fig. 5D; analysis excludes the four slowly activating turn 4 IHCs). Between -30 and +30 $\mathrm{mV}$, the mean activation time constants of the fast- 

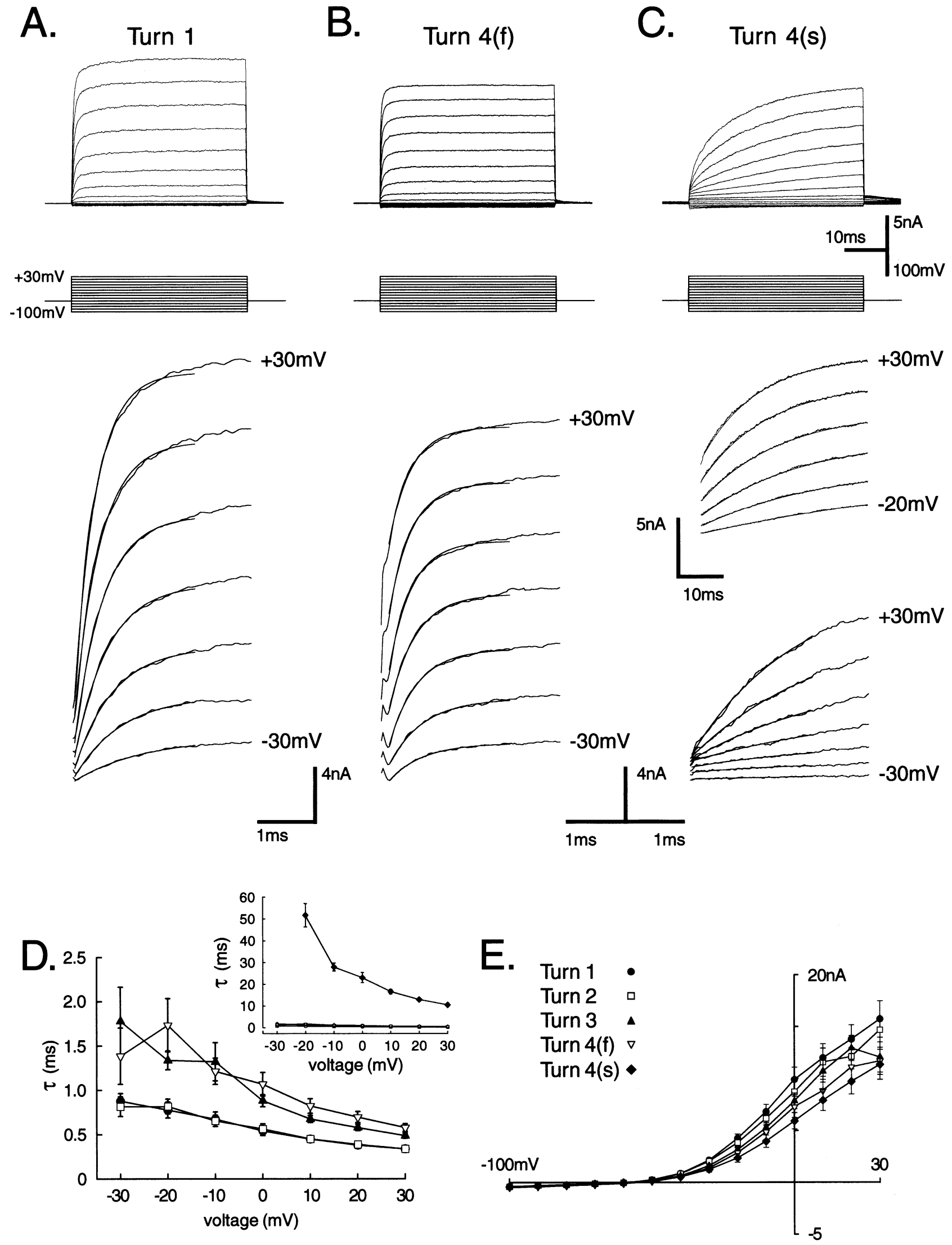
activating outward current records over the initial 2 ms shortened from $0.9 \pm 0.1 \mathrm{~ms}$ to $0.3 \pm 0.03 \mathrm{~ms}$ in turn $1 \mathrm{IHCs}$ and from $1.4 \pm 0.3 \mathrm{~ms}$ to $0.6 \pm 0.04 \mathrm{~ms}$ in turn 4 IHCs $(n=19$; Fig. 5D). IHC slope conductance about $0 \mathrm{mV}$ did not vary across turns, as seen for the voltage-ramp analysis, and the turn 4 IHCs with slower activation kinetics had the same conductance (measured at $40 \mathrm{~ms}$ ) as the faster-activating IHC from all four turns $(p>0.05$, Fig. $5 \mathrm{E})$.

\section{$\mathrm{P} 2 \mathrm{X}$ receptor conductance in $\mathrm{IHC}$ with respect to cell origin}

Direct measurement of the $\mathrm{P} 2 \mathrm{X}$ receptor conductance was achieved by suppression of the $\mathrm{K}_{\mathrm{Ca}}$ conductance under nominally $\mathrm{Ca}^{2+}$-free conditions, along with a high level of intracellular $\mathrm{Ca}^{2+}$ buffering $(10 \mathrm{mM}$ BAPTA). Under these conditions, and using bathapplied ATP, there was no evidence for a $\mathrm{P} 2 \mathrm{Y}$ receptormediated release of intracellular $\mathrm{Ca}^{2+}$ affecting membrane conductance (Sugasawa et al. 1996). At a concentration of ATP $(10 \mu \mathrm{M})$ close to the IHC P2X receptor conductance $E C_{50}$ (Sugasawa et al. 1996), P2X receptor currents exhibited no dependence upon turn of origin ( $p>0.05$, one-way ANOVA; Figs. $6 \mathrm{~A}$ and $\mathrm{C}$ ) and had an overall average of $-681 \pm 70 \mathrm{pA}(n=48$, $\left.V_{\mathrm{h}}=-60 \mathrm{mV}\right)$. This lack of systematic variation with turn of origin was also apparent in the responses to the supramaximal concentration of ATP ( $400 \mu \mathrm{M}$; Figs. $6 \mathrm{~B}$ and $\mathrm{C}$ ). The overall mean inward current response to $400 \mu \mathrm{M}$ ATP was $-1319 \pm 121 \mathrm{pA}(n=42)$. Subsequent application of $1 \mathrm{mM}$ ATP failed to elicit significantly greater inward currents $(p>0.05$, paired $t$-test, $n=5)$. ATP produced reversible depolarizing shifts of the $V_{\mathrm{z}}$ in a dose-dependent manner (to $-38.9 \pm$ $0.9 \mathrm{mV}$ with $10 \mu \mathrm{M}$ ATP, $n=48$; to $-32.3 \pm 0.8 \mathrm{mV}$ with $400 \mu \mathrm{M}$ ATP, $n=42$; compared with the mean $=-50.4 \mathrm{mV}$ in $\mathrm{Ca}^{2+}$-free solution, stated above).

The ATP-gated inward current was associated with an increased slope conductance at potentials negative to $0 \mathrm{mV}$. This $\mathrm{P} 2 \mathrm{X}$ receptor conductance exhibited no dependence on IHC turn of origin $(p>0.05$, oneway ANOVA; Fig. 7). Membrane slope conductance about $-75 \mathrm{mV}$ for all cells increased significantly to a mean of $32.1 \pm 2.2 \mathrm{nS}$ with $10 \mu \mathrm{M}$ ATP and to 47.5 $\pm 3.5 \mathrm{nS}$ with $400 \mu \mathrm{M}$ ATP. There was no significant effect of ATP on IHC conductance about $0 \mathrm{mV}$ (Fig. $7 \mathrm{~B})$ because of inward rectification of the $\mathrm{P} 2 \mathrm{X}$ receptor conductance (Brake et al. 1994).

The net ATP-activated conductance was derived by subtraction of the $I / V$ relationship with superfusion of $\mathrm{Ca}^{2+}$-free solution from the $I / V$ during application of ATP $+\mathrm{Ca}^{2+}$-free. As apparent from the absolute conductances, there was no significant difference $(p$ $>0.05$, one-way ANOVA) in the IHC $\mathrm{P} 2 \mathrm{X}$ receptor conductance about $-75 \mathrm{mV}$ with respect to cell origin (Fig. 7). There was no net $\mathrm{P} 2 \mathrm{X}$ receptor conductance about $0 \mathrm{mV}$ as a result of the inward rectification (described above, Fig. 3B). Overall, the net P2X receptor conductance about $-75 \mathrm{mV}$ averaged $15.4 \pm 1.8$ $\mathrm{nS}$ for $10 \mu \mathrm{M}$ ATP and $31.0 \pm 3.2 \mathrm{nS}$ for $400 \mu \mathrm{M}$ ATP.

\section{DISCUSSION}

The potential for variation in the expression of voltageand ligand-activated conductances to alter the IHC membrane filter properties along the length of the cochlea was investigated. The membrane filter shapes the AC and DC components of the receptor potential which determine the temporal coding of neurotransmitter release during sound stimulation (van Emst et al. 1998; Cheatham and Dallos 1999). The principal finding of this study was the consistency of IHC membrane capacitance and conductance throughout the cochlea. Approximately $40 \%$ of IHC basolateral $\mathrm{K}^{+}$ conductance was modulated by $\mathrm{Ca}^{2+}$. In addition, the apically located ATP-activated ( $\mathrm{P} 2 \mathrm{X}$ receptor) conductance may also influence the sound-induced receptor potential. These data indicate that while the elements
FIG. 5. Activation kinetics of IHC voltage-dependent currents. A. Turn 1 (basal) IHCs exhibit fast-activating outward currents at potentials positive to $-60 \mathrm{mV}$ (voltage range: -100 to $+30 \mathrm{mV}, 10 \mathrm{mV}$ increments, $40 \mathrm{~ms}, V_{\mathrm{h}}=-60 \mathrm{mV}$ ). The initial $3 \mathrm{~ms}$ of current traces for -30 to $+30 \mathrm{mV}$ voltage steps are shown under the voltage protocol. These current traces have been fitted over the initial $2 \mathrm{~ms}$ by a recursive best-fit single exponential function. The time constants $(\tau)$ ranged from $1.1 \mathrm{~ms}$ at $-30 \mathrm{mV}$ to $0.4 \mathrm{~ms}$ at $+30 \mathrm{mV}$. B. Turn 4 (apical) IHC exhibiting similar fast (f) activation kinetics. Single exponential fits for the activation of the outward currents were determined as for A. The time constants varied from $0.6 \mathrm{~ms}$ to $0.4 \mathrm{~ms}$. C. Turn 4 IHCs from a subpopulation which exhibited an additional slower (s) activation component of the outward current response to the depolarizing voltage steps. The single exponential fits for this slower-activating current are shown immediately below the voltage protocol (fitted between 3 and $40 \mathrm{~ms}$ ). These traces had time constants ranging from $59.2 \mathrm{~ms}$ at $-20 \mathrm{mV}$ to $12.0 \mathrm{~ms}$ at $+30 \mathrm{mV}$. This cell also exhibited the fast-activating currents with kinetic properties similar to those of the majority of IHC. The time constants for the initial $3 \mathrm{~ms}$ of current traces ranged from $3.2 \mathrm{~ms}$ at $0 \mathrm{mV}$ to $1.7 \mathrm{~ms}$ at +30 $\mathrm{mV}$ (shown immediately beneath the fits to the slower currents). D. Analysis of the voltage dependence of the activation time constants for IHC of different turns. The majority of the IHCs (turn $1=8$, turn $2=8$, turn $3=18$, turn $4=14 / 23$ ) had rapidly activating currents (symbols as for $\mathbf{E}$ ). A subpopulation of turn 4 IHCs (9/23) had slower time constants; the activation kinetics of this subpopulation of IHCs is shown in relation to rest of the dataset (inset). E. Analysis of the current-voltage relationships (current amplitudes obtained at $40 \mathrm{~ms}$ ) for IHCs from turns 1-4, including subsets of turn 4 fast (f) and slow (s) cells. 

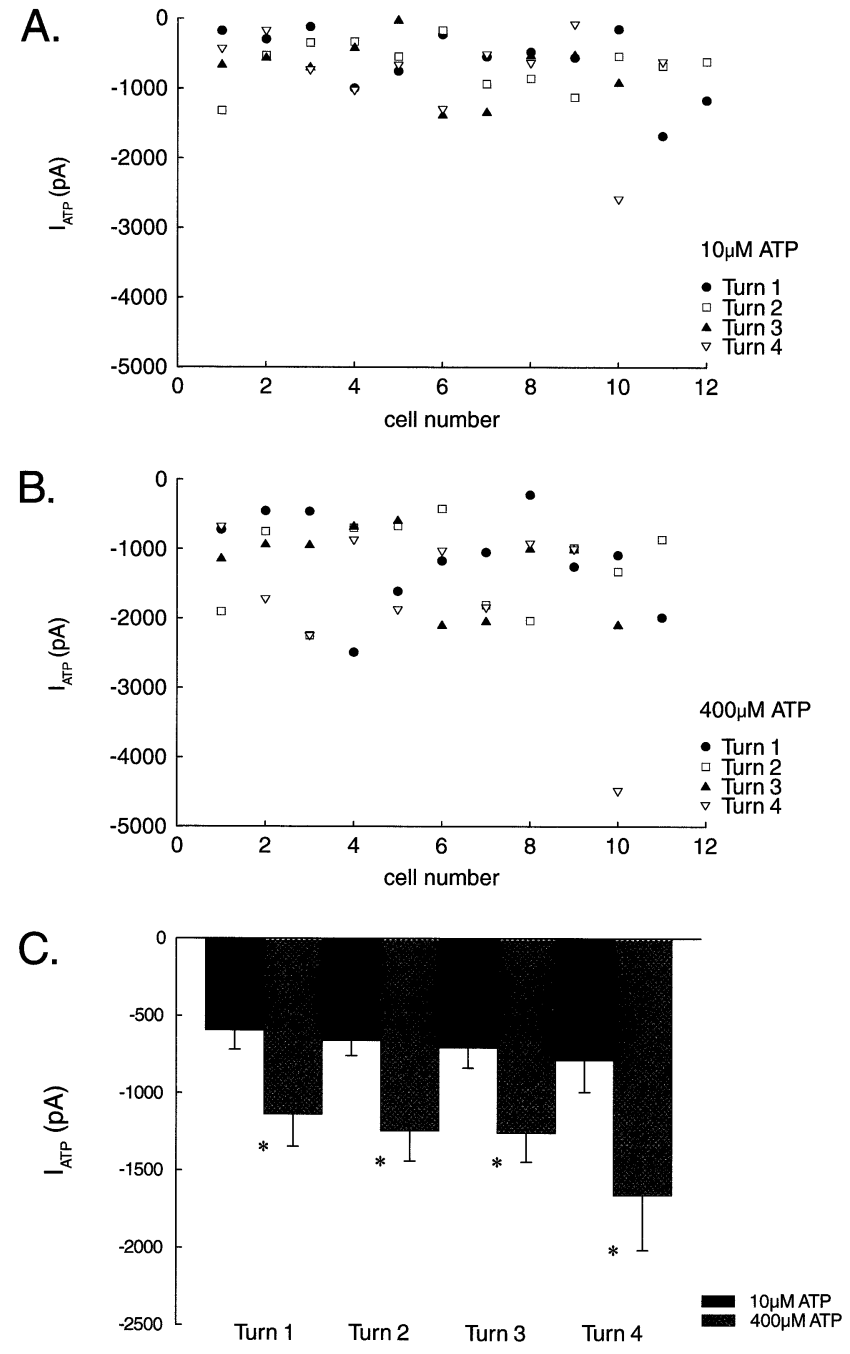

FIG. 6. IHC inward current responses to bath applied 10 and 400 $\mu \mathrm{M}$ ATP in $\mathrm{Ca}^{2+}$-free solution. The net ATP-gated current $\left(\mathrm{V}_{\mathrm{h}}=-60\right.$ $\mathrm{mV}$ ) was measured immediately prior to the voltage ramp used for measurement of slope conductance. A. The current responses to 10 $\mu \mathrm{M}$ ATP showed no systematic variation across the turns of the cochlea ( $n=48, p>0.05$, one-way ANOVA). B. Current responses to $400 \mu \mathrm{M}$ ATP were also independent of cell origin $(n=42, p>$ 0.05, one-way ANOVA). C. Combined net ATP-gated current data for each cochlear turn. Each bin represents the mean for 10-14 IHCs per turn. Error bars indicate \pm SEM. * indicates significant difference $(p>0.05$, unpaired $t$-test for adjacent bars)

defining the IHC membrane filter are constant, local activation of $\mathrm{K}_{\mathrm{Ca}}$ or $\mathrm{P} 2 \mathrm{X}$ conductance would generate significant increases in the corner frequency of the forward transduction transfer function.

These data provide a comprehensive, quantitative analysis of IHC conductance properties. Guinea pig IHCs express a different complement of membrane conductances from that of the adjacent OHCs. In OHCs there is a systematic variation in the principal $\mathrm{K}^{+}$conductance $\left(G_{\mathrm{K}, n}\right)$, with greatest expression in the basal (high-frequency encoding) region (Housley and Ashmore 1992; Mammano and Ashmore 1996;
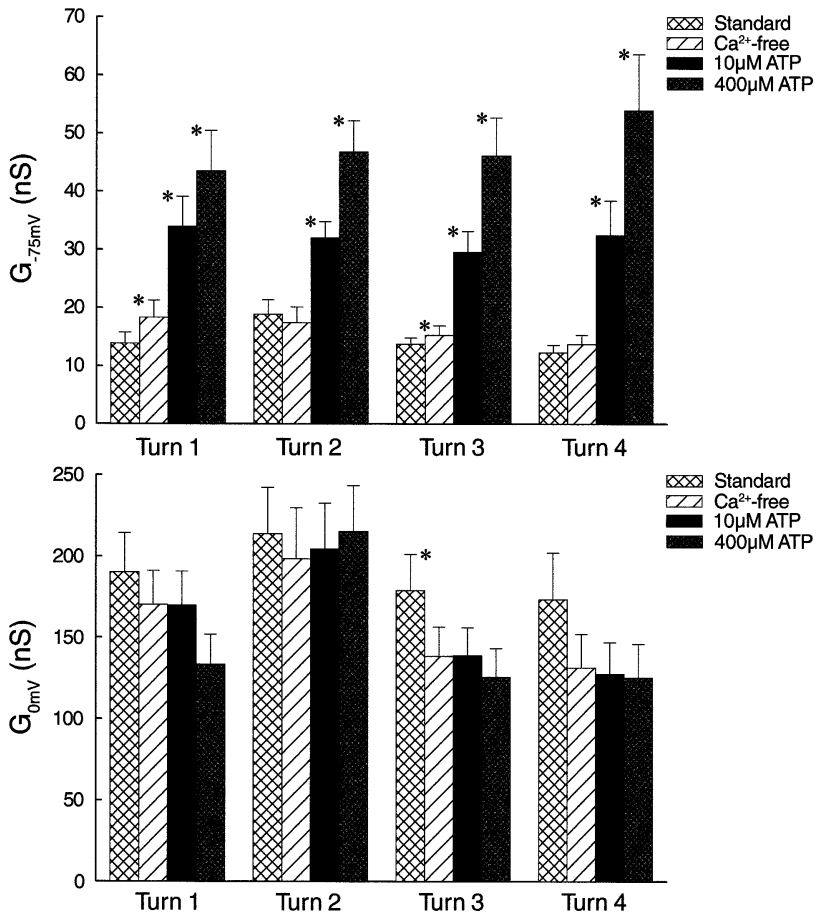

FIG. 7. IHC slope conductance measured during the sequential superfusion of standard solution (steady state with BAPTA dialysis), $\mathrm{Ca}^{2+}$-free solution, $10 \mu \mathrm{M}$ ATP in $\mathrm{Ca}^{2+}$-free solution, and $400 \mu \mathrm{M}$ ATP in $\mathrm{Ca}^{2+}$-free solution. A. Slope conductance measured about $-75 \mathrm{mV}\left(G_{-75 \mathrm{mV}}\right)$. B. Slope conductance measured about $0 \mathrm{mV}$ $\left(G_{0 \mathrm{mv}}\right)$. There was no systematic variation in $G_{-75 \mathrm{mv}}$ and $G_{0 \mathrm{mv}}$ for given solutions across the turns of the cochlea ( $p>0.05$, one-way ANOVA). Each bin represents the mean \pm SEM of 10-19 IHCs per cochlear turn. ${ }^{*}$ indicates significant difference $(p<0.05$, unpaired $t$-test for adjacent bars).

Raybould and Housley 1997). It has been proposed that this increase in $G_{\mathrm{K}, n}$ contributes a tonotopic tuning of the OHC membrane filter which is defined by the time constant $\left[\tau_{\mathrm{m}}=\right.$ input resistance $\left(R_{\mathrm{in}}\right) \times$ membrane capacitance $\left(C_{\mathrm{m}}\right)$ (Hille 1992)]. Thus, reductions of both OHC $R_{\text {in }}$ and $C_{\mathrm{m}}$ toward the base of the cochlea result in $\tau_{\mathrm{m}}$ changing from $11 \mathrm{~ms}$ in the apex to $0.3 \mathrm{~ms}$ in turn 2 (Mammano and Ashmore 1996). Therefore, the attenuation of the response to the sound-modulated receptor potential has a corner frequency $(-f=3 \mathrm{~dB}, f=1 / 2 \pi \tau)$ of approximately $400 \mathrm{~Hz}$ for basal turn OHCs $\left(R_{\mathrm{in}}=22 \mathrm{M} \Omega, C_{\mathrm{m}}=18\right.$ pF; Housley and Ashmore 1992). Preyer et al. (1996) similarly verify the tonotopic variation in OHC corner frequencies, showing an exponential decline from approximately $550 \mathrm{~Hz}$ for cells in the basal turn of the cochlea to $35 \mathrm{~Hz}$ at the apex. In comparison, IHCs at rest (negative to the activation threshold for the $\mathrm{K}^{+}$conductance, $-55 \mathrm{mV}$ ) for any region of the organ of Corti can now be modeled with $R_{\text {in }}=140$ $\mathrm{M} \Omega$ around their resting potential and $C_{\mathrm{m}}=10 \mathrm{pF}$. The present study clearly demonstrates the narrow 
range of IHC conductance between -60 and -90 $\mathrm{mV}$ irrespective of cell origin (Fig. 4A). Thus, the average $\tau_{\mathrm{m}}$ for a guinea pig IHC is approximately 1.4 ms with a predicted corner frequency of approximately $115 \mathrm{~Hz}$. At the point of $\mathrm{K}^{+}$conductance activation, the corner frequency has been estimated at $480-940 \mathrm{~Hz}$ in isolated IHCs (Kros and Crawford 1990). Our data suggest that this estimate is valid throughout the cochlea.

Our measurements of IHC membrane time constant and corner frequency also agree with the lower end of the estimate of a 0.9 ms time constant and a 178-1 Hz corner frequency for basal turn guinea pig IHCs, based on high-impedance intracellular recordings in vivo (Sellick and Russell 1980). While no data are available on the temperature sensitivity of IHC conductance, our in vitro data closely matches these in vivo measurements when corrected using a general $Q_{10}$ value of 1.3 (Hille 1992). The fall-off in basal (first) turn IHC AC receptor potentials from approximately $300 \mathrm{~Hz}$ (Palmer and Russell 1986) has been ascribed to the low-pass characteristics of the IHC filter. An estimated time constant of $0.34 \mathrm{~ms}$ and a corner frequency of $472 \mathrm{~Hz}$ have previously been modeled for this filter for guinea pig IHCs from all regions of the cochlea in vivo (Dallos 1984). The current study demonstrates that the estimates of the membrane time constant will necessarily vary with recording method and condition of the IHCs, which in turn will affect the activation level of the $\mathrm{K}_{\mathrm{Ca}}$ channels. Our estimate is likely to be at the lower end of the experimental range because of the $\mathrm{Ca}^{2+}$ buffering that we achieved in our whole-cell recordings. Nevertheless, the key element of the present analysis is the demonstration of the constancy of the IHC low-pass membrane filter throughout the cochlea. This is in contrast with all other cochlear hair cell systems studied.

Our findings are also supported by recent in vivo recordings which show the development of phase lags in IHC receptor potentials relative to basilar membrane motion as stimulus frequency increases are independent of IHC origin (Cheatham and Dallos 1999). This roll-off in phase-related encoding of sound, attributable to the membrane filter, is likely to underlie the limited dynamic range of phase-locked auditory nerve firing, at least in the guinea pig (Palmer and Russell 1986). Thus, the IHC membrane filter may be modeled as a function which receives pretuned input from the cochlear amplifier and changes dynamically with alterations in basolateral $\mathrm{K}^{+}$channel activation (modeled by van Emst et al. 1998).

Using pharmacological channel blockers, Kros and Crawford (1990) dissected two separate $\mathrm{K}^{+}$currents from turns 3 and 4 guinea pig IHCs, which exhibited widely differing activation time constants. They defined a fast-activating $\mathrm{K}^{+}$current $\left(I_{\mathrm{K}, \mathrm{f}}\right)$ in the presence of 4-aminopyridine (4AP), which was best-fitted by a second-order exponential with voltage-dependent and independent activation time constants. At room temperature, the voltage-dependent component varied between approximately 1.5 and $0.8 \mathrm{~ms}$ over the activation range, while the voltage-independent time constant was approximately $0.25 \mathrm{~ms}$. A slower 4APsensitive $\mathrm{K}^{+}$current $\left(I_{\mathrm{K}, \mathrm{s}}\right)$ was also isolated using tetraethylammonium (TEA). The activation kinetics for this conductance had two voltage-dependent time constants that ranged between approximately 1 and $10 \mathrm{~ms}$ and between 12 and $28 \mathrm{~ms}$. While both $I_{\mathrm{K}, \mathrm{f}}$ and $I_{\mathrm{K}, \mathrm{s}}$ would contribute to the activation kinetics of our whole-cell currents, we have shown that IHC conductance (in the absence of $\mathrm{K}^{+}$channel blockers) is wellfitted by a first-order exponential function with time constants similar to the voltage-dependent $I_{\mathrm{K}, \mathrm{f}}$ component. In our study, the IHC activation kinetics across turns varied between approximately 0.9 and $1.8 \mathrm{~ms}$, close to the activation threshold for turns 1 and 2 IHCs and turns 3 and 4 IHCs, respectively. Thus, the IHCs from the more apical turns activated approximately half as fast as the higher-frequency-encoding IHCs. However, in comparison with the subpopulation of slowly activating IHCs from turn 4, these activation kinetics are remarkably consistent (see Fig. 5D, inset). Indeed, the data for the fast-activating IHCs from all four turns lie within the range of activation time constants for $I_{\mathrm{K}, \mathrm{f}}$ described by Kros and Crawford (1990). The slowly activating outward current of the subpopulation of turn 4 IHCs had voltage-dependent time constants considerably slower than those reported for $I_{\mathrm{K}, \mathrm{s}}$ (Kros and Crawford 1990) and slower than those activation time constants of the TEA-sensitive $\mathrm{K}_{\mathrm{Ca}}$ conductance in OHCs $(30 \mathrm{~ms}$ at $-30 \mathrm{mV}$; Housley and Ashmore 1992).

In mouse IHC, expression of $I_{\mathrm{K}, \mathrm{f}}$ coincides with the onset of hearing function (Kros et al. 1998) and its pharmacology links this conductance to $\mathrm{K}_{\mathrm{Ca}}$ channel activity. In addition, excised patch recordings of $\mathrm{K}_{\mathrm{Ca}}$ channels from adult guinea pig IHCs show characteristics consistent with the $I_{\mathrm{K}, \mathrm{f}}$ classification (Appenrodt and Kros 1997). Thus, the present study shows the potential physiological significance of $\mathrm{Ca}^{2+}$ signaling to modulate the major IHC membrane conductance.

In contrast to the mammalian cochlea, lower vertebrates, such as birds, turtles, and frogs, do not separate frequencies efficiently along their auditory papilla and principally rely on intrinsic electrical tuning of the sensory hair cells (Fettiplace and Fuchs 1999). This electrical filter arises from an interplay between voltage-gated $\mathrm{Ca}^{2+}$ channels and $\mathrm{K}_{\mathrm{Ca}}$ channels (Hudspeth and Lewis 1988) and a tonotopic variation in $\mathrm{K}_{\mathrm{Ca}}$ channel conductance and kinetics (Art et al. 1993; Art and Fettiplace 1987; Wu et al. 1995; Fettiplace and Fuchs 
1999). Isolated guinea pig IHC current clamp experiments (Kros and Crawford 1990) failed to detect the electrical resonance intrinsic to such systems. While IHC $\mathrm{K}_{\mathrm{Ca}}$ channel activation by $\mathrm{Ca}^{2+}$ influx through voltage-gated $\mathrm{Ca}^{2+}$ channels has been reported (Dulon et al. 1995), our demonstration of the constancy in IHC $\mathrm{K}^{+}$channel properties precludes the variation in ion channels that form the basis of electrical tuning in non-mammalian vertebrates.

Our quantitative analysis of the P2X receptor conductance provides further information on the regulation of IHC membrane filter properties along the cochlea. The present study shows that the proportion of IHC P2X receptor conductance to voltage-dependent slope conductance measured about $-75 \mathrm{mV}$ is approximately $3: 1$. This is similar to the ratio previously determined for OHCs (Raybould and Housley 1997). We estimate that IHCs possess approximately 1500 ATP-gated ion channels, irrespective of origin. This is based on a $31 \mathrm{nS}$ IHC P2X receptor conductance and the $21 \mathrm{pS}$ unitary conductance reported for ATP-gated ion channels assembled from $\mathrm{P}_{2} \mathrm{X}_{2}$ receptor subunits (Evans 1996). In comparison, the number of ATPgated ion channels on OHCs increases from approximately 3000 in the apex to 8000 in the basal turn (Raybould and Housley 1997). This gradient is in parallel with the tonotopic increase in OHC $G_{\mathrm{K}, n}$. Therefore, it seems likely that regulation of $\mathrm{P} 2 \mathrm{X}$ receptor expression in both IHCs and OHCs is linked to the level of $\mathrm{K}^{+}$channel expression.

The functional significance of the expression of P2X receptors by IHCs must be considered within the context of the emerging scheme of extracellular nucleotide signaling in the inner ear. The expression of $\mathrm{P} 2 \mathrm{X}$ receptors by the majority of cochlear tissues supports the concept that extracellular ATP acts within scala media as a humoral homeostatic control factor that regulates the electrochemical driving force for sound transduction (Thorne and Housley 1996; Housley and Ryan 1997; Housley et al. 1998a,b; Kirk and Yates 1998; Muñoz et al. 1999; Housley 1998, 2000, 2001). The positioning of ATP-gated ion channels in high density on hair cell stereocilia (Housley et al. 1992, 1999; Mockett et al. 1994; Sugasawa et al. 1996) provides a direct electrical pathway in parallel with the mechanoelectric transducer channels also present on the stereocilia (Denk et al. 1995). Activation of the P2X receptor conductance by ATP would reduce the hair cell receptor potential via an electrical shunt that alters the electrochemical driving force for sound transduction (Ashmore et al. 1992; Housley et al. 1992, 1998a, 1999). In addition, the ATP-induced depolarization of the IHCs would have the ancillary effect of recruiting additional basolateral $\mathrm{K}^{+}$conductance, providing a synergism that would significantly decrease the mem- brane time constant and raise the corner frequency of the membrane filter.

In conclusion, the present study provides a comprehensive analysis of the membrane properties of IHC along the guinea pig cochlea. A feature of these sensory hair cells is their remarkable uniformity in membrane capacitance, in the kinetics and amplitude of the voltage-activated conductances, and in the related expression of the ATP-activated P2X receptor conductance. These observations suggest that transduction of sound information by IHC is constant along the cochlea and that frequency and intensity coding by neurotransmitter release arises from elements upstream of the membrane filter.

\section{ACKNOWLEDGMENTS}

This research was funded with the assistance of the Health Research Council of New Zealand, the New Zealand Lottery Grants Board, the Deafness Research Foundation of New Zealand, and the Wallath Trust. Denise Greenwood is thanked for technical support.

\section{REFERENCES}

APPENRODT P, Kros CJ. Single-channel recordings of large conductance $\mathrm{Ca}^{2+}$ activated $\mathrm{K}^{+}$channels from guinea-pig inner hair cells. J. Physiol. 501.P:147P, 1997.

Art JJ, Fettiplace R, Wu Y-C. The effects of low calcium on the voltage-dependent conductances involved in tuning of turtle hair cells. J. Physiol. 470:109-125, 1993.

ART JJ, FETTIPLACE R. Variation of membrane properties in hair cells isolated from the turtle cochlea. J. Physiol. 385:207-242, 1987.

ARt JJ, Crawford AC, FetTiPLACE R. Electrical resonance and membrane currents in turtle cochlear hair cells. Hear. Res. 22:3136, 1986.

AsHMORE JF. A fast motile response in guinea-pig outer hair cells: the cellular basis of the cochlear amplifier. J. Physiol. 388:323$347,1987$.

AsHMORE JF. The G. L. Brown prize lecture: The cellular machinery of the cochlea. Exp. Physiol. 79:113-134, 1994.

Ashmore JF, Kolston PJ. Hair cell based amplification in the cochlea. Curr. Opin. Neurobiol. 4:503-508, 1994.

Ashmore JF, Housley GD, Kolston PJ. Two control systems for the outer hair cell motor. In: Cazals Y, Demaney L, Horner K, (eds) Advances in the Biosciences. Pergaman Press Oxford, 1992, 19-23.

BRAKE AJ, WAGENBACH MJ, Julius D. New structural motif for ligandgated ion channels defined by an ionotropic ATP receptor. Nature 371:519-523, 1994.

Cheatham MA, Dallos P. Response phase: a view from the inner hair cell. J. Acoust. Soc. Am. 105:799-810, 1999.

DALLOS P. Some electrical circuit properties of the organ of Corti. II. Analysis including reactive elements. Hear. Res. 14:281-291, 1984.

Dallos P. The active cochlea. J. Neurosci. 12:4575-4585, 1992.

Dallos P, Evans BN. High-frequency motility of outer hair cells and the cochlear amplifier. Science 267:2006-2009, 1995.

Denk W, Holt JR, ShePHerd GMG, CoREy DP. Calcium imaging of single stereocilia in hair cells: localization of transduction channels at both ends of tip links. Neuron 15:1311-1321, 1995. 
Dulon D, Sugasawa M, Blanchet C, Erostegui C. Direct measurements of $\mathrm{Ca}^{2+}$-activated $\mathrm{K}^{+}$currents in inner hair cells of the guinea-pig cochlea using photolabile $\mathrm{Ca}^{2+}$ chelators. Pflügers Archiv. 430:365-373, 1995.

EvANS RJ. Single channel properties of ATP-gated cation channels (P2X receptors) heterologously expressed in Chinese hamster ovary cells. Neurosci. Lett. 212:212-214, 1996.

Evans RJ, Lewis C, Virginio C, Lundstrom K, Buell G, Surprenant A, NORTH RA. Ionic permeability of, and divalent cation effects on, two ATP-gated cation channels (P2X receptors) expressed in mammalian cells. J. Physiol. 497:413-422, 1996.

Fettiplace R, Fuchs PA. Mechanisms of hair cell tuning. Annu. Rev. Physiol. 61:809-834, 1999.

GILL SS, SALT AN. Quantitative differences in endolymphatic calcium and endocochlear potential between pigmented and albino guinea pigs. Hear. Res. 113:191-197, 1997.

Hille B. Ionic channels of excitable membranes. Sinauer Assoc. Sunderland MA, USA, 1992.

Holley MC, Ashmore JF. On the mechanism of a high-frequency force generator in outer hair cells isolated from the guinea pig cochlea. Proc. R. Soc. Lond. B Biol. Sci. 232:413-429, 1988.

Housley GD, AsHMORE JF. Ionic currents of outer hair cells isolated from the guinea-pig cochlea. J. Physiol. 448:73-98, 1992.

Housley GD, GREENWOOD D, AsHMORE JF. Localization of cholinergic and purinergic receptors on outer hair cells isolated from the guinea-pig cochlea. Proc. R. Soc. Lond. B Biol. Sci. 249:265273, 1992.

Housley GD, Greenwood D, Mockett BG, Muñoz DJB, Thorne PR. Differential actions of ATP-activated conductances in outer and inner hair cells isolated from the guinea-pig organ of corti: A humoral purinergic influence on cochlear function. In: Duifhuis H, Horst JW, Van Dijk P, Van Netten SM, (eds) Biophysics of hair cell sensory systems. World Scientific Singapore, 1993, 116-123.

HOUSLEY GD, RYAN AF. Cholinergic and purinergic neurohumoral signalling in the inner ear: A molecular physiological analysis. Audiol. Neuro-Otol. 2:92-110, 1997.

HousLEy GD. Extracellular nucleotide signalling in the inner ear. Mol. Neurobiol. 16:21-47, 1998.

Housley GD, RaYBould NP, ThORNE PR. Fluorescence imaging of $\mathrm{Na}^{+}$influx via P2X receptors in cochlear hair cells. Hear. Res. 119:1-13, 1998a.

Housley GD, LuO L, RyAn AF. Localization of mRNA encoding the $\mathrm{P}_{2} \mathrm{X}_{2}$ receptor subunit of the adenosine 5 '-triphosphate-gated ion channel in the adult and developing rat inner ear by in situ hybridization. J. Comp. Neurol. 393:403-414, 1998b.

Housley GD, Kanjhan R, Raybould NP, GReenwood D, Salih SG, Järlebark L, Burton LD, Setz VCM, Cannell MB, Soeller C, Christie DL, Usami S, Matsubara A, Yoshie H, Ryan AF, Thorne PR. Expression of the $\mathrm{P}_{2} \mathrm{X}_{2}$ receptor subunit of the ATP-gated ion channel in the cochlea: Implications for sound transduction and auditory neurotransmission. J. Neurosci. 19:8377-8388, 1999.

HousLEY GD. Physiological effects of extracellular nucleotides in the inner ear. Clin. Exp. Pharm. Physiol. 27:575-580, 2000.

HousLEY GD. Nucleoside and nucleotide transmission in sensory systems. In: Abbracchio MP, Williams M, (eds) Purinergic and Pyrimidinergic Signalling I-Molecular, Nervous and Urogentary System Function. Handbook of Experimental Pharmacology, 151/ I Berlin: Springer-Verlag, 2001, 339-369.

HUdSPETH AJ, LEWIS RS. Kinetic analysis of voltage- and ion-dependent conductances in saccular hair cells of the bull-frog, Rana catesbeiana. J. Physiol. 400:237-274, 1988.

HudsPeth AJ. Sensory transduction in the ear. In: Kandel ER, Schwartz JH, Jessell TM, (eds) Principles of neural science. New York: McGraw-Hill, 2000, 614-624.
Jones EMC, Gray-Keller M, ART JJ, FetTiPLACE R. The functional role of alternative splicing of $\mathrm{Ca}^{2+}$-activated $\mathrm{K}^{+}$channels in auditory hair cells. Ann. NY Acad. Sci. 868:379-385, 1999a.

Jones EMC, Gray-Keller M, Art JJ, Fettiplace R. The role of $\mathrm{Ca}^{2+}$-activated $\mathrm{K}^{+}$channel spliced variants in the tonotopic organisation of the turtle cochlea. J. Physiol. 518:653-665, 1999b.

Kaczorowski GJ, Knaus H-G, Leonard RJ, Mcmanus OB, Garcia ML. High conductance calcium-activated potassium channels; structure, pharmacology, and function. J. Bioenerg. Biomembr. 28:255-267, 1996.

Kalinec F, Holley MC, Iwasa KH, Lim DJ, Kachar B. A membranebased force generation mechanism in auditory sensory cells. Proc. Natl. Acad. Sci. USA 89:8671-8675, 1992.

KIRK DL, YATES GK. ATP in endolymph enhances electrically-evoked oto-acoustic emissions from the guinea pig cochlea. Neurosci. Lett. 250:149-152, 1998.

Kolston PJ. Comparing in vitro, in situ, and in vivo experimental data in a three-dimensional model of mammalian cochlear mechanics. Proc. Natl. Acad. Sci. USA 96:3676-3681, 1999.

Kros CJ, RUPPERSBERG JP, RÜSCH A. Expression of a potassium current in inner hair cells during development of hearing in mice. Nature 394:281-284, 1998.

Kros CJ, Crawford AC. Potassium currents in inner hair cells isolated from the guinea-pig cochlea. J. Physiol. 421:263-291, 1990.

Mammano F, AshmoRe JF. Differential expression of outer hair cell potassium currents in the isolated cochlea of the guinea-pig. J. Physiol. 496:639-646, 1996.

Mockett BG, Housley GD, Thorne PR. Fluorescence imaging of extracellular purinergic receptor sites and putative ecto-ATPase sites on isolated cochlear hair cells. J. Neurosci. 14:6992-7007, 1994.

MounTAIn DC. Electromechanical properties of hair cells. Neurobiology of hearing. In: Altschuler RA, Hoffman, DW, Bobbin RP, (eds) The cochlea. New York: Raven Press, 1986, 77-90.

Muñoz DJ, Thorne PR, Housley GD. P2X receptor-mediated changes in cochlear potentials arising from exogenous adenosine 5'-triphosphate in endolymph. Hear. Res. 138:56-64, 1999.

Navaratnam DS, Bell TJ, Tu TD, Cohen EL, Oberholtzer JC. Differential distribution of $\mathrm{Ca}^{2+}$-activated $\mathrm{K}^{+}$channel splice variants among hair cells along the tonotopic axis of the chick cochlea. Neuron 19:1077-1085, 1997.

PALMER AR, Russell IJ. Phase-locking in the cochlear nerve of the guinea-pig and its relation to the receptor potential of inner hair cells. Hear. Res. 24:1-15, 1986.

Preyer S, Renz S, Hemmert W, Zenner H-P, Gummer AW. Receptor potential of outer hair cells isolated from base to apex of the adult guinea-pig cochlea: Implications for cochlear tuning mechanisms. Aud. Neurosci. 2:145-157, 1996.

Pujol R, Lenoir M, Ladrech S, Tribillac F, Rebillard G. Correlation between the length of outer hair cells and the frequency coding of the cochlea. In: Cazals Y, Demaney L, Horner K, (eds) Auditory physiology and perception. Oxford: Pergamon Press, 199245-52.

Raybould NP, Housley GD. Variation in expression of the outer hair cell P2X receptor conductance along the guinea-pig cochlea. J. Physiol. 498:717-727, 1997.

Rosenblatt KP, Sun Z, Heller S, Hudspeth AJ. Distribution of $\mathrm{Ca}^{2+}$-activated $\mathrm{K}^{+}$channel isoforms along the tonotopic gradient of the chicken's cochlea. Neuron 19:1061-1075, 1997.

SANTOS-SACCHI J. On the frequency limit and phase of outer hair cell motility: effects of the membrane filter. J. Neurosci. 12:19061916, 1992.

Sellick PM, Russell IJ. The responses of inner hair cells to basilar membrane velocity during low frequency auditory stimulation in the guinea pig cochlea. Hear. Res. 2:439-446, 1980.

Sugasawa M, Erostegui C, Blanchet C, Dulon D. ATP activates 
non-selective cation channels and calcium release in inner hair cells of the guinea-pig cochlea. J. Physiol. 491:707-718, 1996.

Toro L, Wallner M, Meera P, TANaka Y. Maxi-K $\mathrm{K}_{\mathrm{Ca}}$, a unique member of the voltage-gated K channel superfamily. News Physiol. Sci. 13:112-117, 1998.

THORNe PR, HousLey GD. Purinergic signalling in sensory systems. Semin. Neurosci. 8:233-246, 1996.

van EmST MG, Giguere C, SMOOREnburg GF. The generation of DC potentials in a computational model of the organ of Corti: effects of voltage-dependent $\mathrm{K}^{+}$channels in the basolateral membrane of the inner hair cell. Hear. Res. 115:184-196, 1998.

Wu YC, ARt JJ, Goodman MB, Fettiplace R. A kinetic description of the calcium-activated potassium channel and its application to electrical tuning of hair cells. Prog. Biophys. Mol. Biol. 63:131$158,1995$.

Zheng J, Shen W, He DZ, Long KB, Madison LD, Dallos P. Prestin is the motor protein of cochlear outer hair cells. Nature 405:149$155,2000$. 